\title{
Fermentation of dietary fibre in the intestinal tract: comparison between man and rat
}

\author{
BY MARGARETA NYMAN AND NILS-GEORG ASP \\ Department of Food Chemistry, Chemical Centre, University of Lund, Lund, Sweden \\ AND JOHN CUMMINGS AND HUGH WIGGINS \\ MRC Dunn Clinical Nutritional Laboratory, Old Addenbrookes Hospital, Cambridge
}

(Received 11 March 1985 - Accepted 23 December 1985)

1. The breakdown and faecal bulking capacity of dietary fibre preparations from wheat bran, apple, cabbage, carrot, and guar gum were compared in man and rat.

2. The degradation of the fibre showed good correlation between man and rat $(r 0.99$, regression coefficient 0.86$)$. Wheat bran was the least well-digested, 66 and $59 \%$ of the neutral sugars being excreted in faeces of man and rat respectively. The breakdown of the fibre in apple, cabbage, carrot and guar gum was more complete and 4-29\% of the neutral sugars were recovered in faeces.

3. The main dietary fibre constituents in each preparation were degraded to a similar extent in man and rat. The main dietary fibre constituents of apple, carrot, cabbage and guar gum were almost completely degraded. Of the xylose in wheat bran $45 \%$ (man) and $48 \%$ (rat) were recovered in faeces. However, the percentage excretion of glucose and arabinose from bran was higher in man.

4. A faecal glucan other than cellulose was identified in human faeces after guar gum, and has been provisionally identified as starch. No such glucan occurred in rat faeces.

5. A good correlation between the faecal bulking capacity in man and rat was seen ( $r 0.97$, regression coefficient 0.56 ). Wheat bran had the best bulking capacity, while that of apple, cabbage, carrot and guar gum was less pronounced. Faecal bulking was inversely related to the amount of fibre which was water-soluble in each preparation.

6. It is concluded that this rat experimental model is useful for the prediction of fermentative breakdown and bulking capacity of dietary fibre in man. However, more comparative studies are needed to evaluate animal experiments regarding other physiological effects of dietary fibre.

The extent of fermentative breakdown of dietary fibre in man is important in relation to its physiological effects (Cummings, 1981; Vahouny \& Kritchevsky, 1982). Dietary fibre which is largely resistant to bacterial degradation, such as that from wheat bran, has good bulking capacity in the gut while easily-fermented dietary fibre, such as that found in non-cereal foods, can be utilized as a source of energy by bacteria (Mason \& Palmer, 1973) and also by man (McNeil et al. 1978). Fermentation increases colonic bacterial activity and leads to changes in bile acid and nitrogen metabolism (Cummings, 1983a) and the synthesis of vitamins (Rotenberg et al. 1982). The possible protective effect of dietary fibre against large-bowel cancer may be related to the metabolic activity of the intestinal flora (Cummings \& Branch, 1982).

The extent of fermentation of fibre is influenced by a number of factors, such as water-solubility, chemical structure of the fibre (Cummings, 1982; Nyman \& Asp, 1982), lignification (Dekker \& Richards, 1973), particle size (Heller et al. 1980), other components of the diet and the amount ingested (Keys et al. 1970). Processing of dietary fibre may also affect its degradation. Björck et al. (1984) demonstrated that dietary fibre from extruded wheat flour was more extensively degraded in rats than dietary fibre of unprocessed wheat flour, and Wyman et al. (1976) suggested that the faecal bulking effect of raw bran in man was more pronounced than that of cooked bran.

Balance studies on humans are complicated and time-consuming. Consequently there is a need for a simpler model to predict the extent of dietary fibre fermentation in human nutrition. However, there are differences between man and rat (e.g. bigger caecum in rat) 
that may be important for the bacterial degradation of dietary fibre. Van Soest et al. (1983) have done comparative studies on the fermentation of dietary fibre in man and other animals, and concluded that in man it was more extensive than that in rats but less than that in swine.

The present study reports a detailed comparison between man and rat of intestinal degradation and faecal bulking capacity of dietary fibre from wheat bran, apple, cabbage, carrot and guar gum.

\section{MATERIALS AND METHODS}

\section{Dietary fibre preparations}

Dried wheat bran, apple, cabbage and carrot were extracted twice for $3 \mathrm{~h}$ with hot aqueous methanol $(850 \mathrm{ml} / 1$ water $)$, then, after filtration, with acetone, and finally air-dried. The materials were ground, sieved and the particles retained between 0.5 and $1.4 \mathrm{~mm}$ sieves used for the feeding studies. Guar gum was obtained from the Hercules Powder Co., London. The dietary fibre preparations were stored at $-20^{\circ}$ until analysed. The same batches of the fibre were tested both in man and in the rat. Further details of the methods of preparation have been reported previously (Cummings et al. 1978).

\section{Human experiments}

Diets. Throughout the study the subjects ate a controlled basal diet which contained normal food and was of the following composition $(\mathrm{g} / \mathrm{kg}$ dry matter): protein 142 , carbohydrates 642 , fat 180 , dietary fibre 37 . During one dietary period $20-30 \mathrm{~g}$ fibre preparation/d, corresponding to $28-35 \mathrm{~g}$ fibre $/ \mathrm{kg}$ dry matter, were added to the basal diet. Thus, the total amount of fibre in the diet was $64-70 \mathrm{~g} / \mathrm{kg}$. Further details of these studies have been presented elsewhere (Cummings et al. 1978).

Experimental. Nineteen healthy male volunteers, aged 20-38 years, took part in the study. Each subject took the controlled basal diet for 3 weeks. Faeces were collected throughout the 3-week period and for 1 week afterwards, each stool being collected separately into a plastic bag and stored at $-20^{\circ}$. During another 3-week period additional fibre was added to the basal diet. At least 3 weeks elapsed between the two dietary periods to ensure that one dietary period had no residual effect on the next one. All the subjects took ten radio-opaque pellets with each meal $(30 / \mathrm{d})$ throughout the study as markers for faecal output. Six men took fibre from more than one source (Cummings et al. 1978).

Fibre analyses. Fibre in the diet was obtained by calculations from food tables (Paul \& Southgate, 1978). Faecal carbohydrates were measured by gas-liquid chromatography (GLC) after hydrolysis of non-cellulosic polysaccharides with $1 \mathrm{M}$-sulphuric acid. Cellulose was measured by a colorimetric assay of the glucose released when the insoluble residue from the $\mathrm{I} \mathrm{M}-\mathrm{H}_{2} \mathrm{SO}_{4}$ hydrolysis was incubated with $12 \mathrm{M}-\mathrm{H}_{2} \mathrm{SO}_{4}$.

\section{Rat experiments}

Diets. The basal diet contained $(\mathrm{g} / \mathrm{kg}$ dry matter): protein in the form of casein (ANRC reference protein; ICN Nutritional Biochemicals, Cleveland, Ohio) 100, maize starch (AB Risenta, Sweden) 690, sucrose (Swedish Sugar Co. AB) 100, fat 50, vitamins including choline chloride 10 , minerals 50 . Further details regarding vitamin and mineral mixtures have been described previously (Nyman \& Asp, 1982). The dietary fibre preparations replaced some of the maize starch to give $100 \mathrm{~g}$ dietary fibre $/ \mathrm{kg}$ dry matter. This concentration of dietary fibre has been routinely used in the rat model (Nyman \& Asp, 1982, $1985 a, b)$. A lower concentration of wheat-bran fibre $(48 \mathrm{~g} / \mathrm{kg})$ and pectin fibre $(42 \mathrm{~g} / \mathrm{kg})$ have been shown to be fermented to a similar extent (Nyman \& Asp, 1985b). The diets were mixed and given as powders. 
Animals. Male Sprague-Dawley rats, 3-weeks-old, with an initial weight of $75 \mathrm{~g}$, were placed individually in metabolism cages and divided into groups of five (Nyman \& Asp, 1982). This number of rats is used routinely in the rat model (Nyman \& Asp, 1982) and has also been shown to give a high reproducibility. Faecal recovery of the same batch of pectin fibre (Nyman \& Asp, 1982, 1985b) and refined wheat flour fibre (Nyman et al. 1985; Björck et al. 1986) has been shown to be similar on different occasions. Food intake was restricted to $10 \mathrm{~g}$ dry weight/d and water was provided ad lib. A $4 \mathrm{~d}$ adaptation period was followed by a $5 \mathrm{~d}$ balance period, when feed residues and faeces were collected. The weight of the rats increased from a mean of $90 \mathrm{~g}$ to $110 \mathrm{~g}$ during the balance period. Faeces were removed every day, frozen at $-20^{\circ}$ and lyophilized (Nyman \& Asp, 1982). Faeces were then weighed, milled to pass a $0.4 \mathrm{~mm}$ screen, and stored at $-20^{\circ}$ until analysed.

Fibre analyses. Dietary fibre in the various preparations was isolated by the gravimetric method of Asp et al. (1983), using digestion with Termamyl (120L; Novo, Copenhagen), pepsin (no. 7190; Merck, Darmstadt) and pancreatin (no. P-1750; Sigma, St Louis, Mo). The monomeric composition of the neutral sugars in the fibre residues and in faeces was assayed by GLC as the alditol acetates (Sawardeker et al. 1965). Hydrolysis was started in $\mathrm{H}_{2} \mathrm{SO}_{4}(720 \mathrm{ml} / 1 ; 2 \mathrm{ml} / 100 \mathrm{mg})$ at room temperature for $2 \mathrm{~h}$. $\mathrm{The}_{2} \mathrm{H}_{2} \mathrm{SO}_{4}$ was then diluted to $0.36 \mathrm{M}$ and refluxed for $6 \mathrm{~h}$ (Theander \& $\AA$ man, 1979). The insoluble residue was measured as Klason lignin. Allose was used as the internal standard in the GLC assays. The amount of uronic acids in feed and in faeces was measured with a decarboxylation method (Theander \& $\AA$ man, 1979). All dietary fibre constituents were expressed as their polymers, i.e. weight of monomer $\times 0.9$. In addition, a correction for hydrolytic losses, detector response and recovery in the GLC method was made by running the GLC procedure with known sugar standards.

The sum of neutral sugar polymers, uronic acid polymers and Klason lignin amounted to $96-103 \%$ of the total dietary fibre measured gravimetrically according to Asp et al. (1983).

\section{Calculations}

Faecal excretion of dietary fibre components, in the human and rat experiments, was corrected for basal excretion, i.e. the faecal excretion of dietary fibre constituents on the basal diet. In the rat experiments the glucans excreted in faeces were also corrected for the free glucose present.

\section{Statistical evaluation}

The results in the tables have been evaluated by Student's $t$ test (two-tailed). In Table 1 a modified $t$ test has been used due to the unequal variances. The correlation studies in Figs. 1 and 2 have not been subjected to any test of hypothesis. The correlation coefficient has been used only as a describing unit of measurement.

\section{RESULTS AND DISCUSSION}

Fermentation of neutral sugars

Wheat bran. The wheat bran preparation contained $597 \mathrm{~g}$ dietary fibre $/ \mathrm{kg}$ consisting mainly of arabinose, xylose, glucose and lignin in expected proportions (Table 1).

The fermentative breakdown of the dietary fibre saccharides averaged $34 \%$ in man and $41 \%$ in rat (Table 1 and Fig. 1). The faecal recovery of the main components, arabinose, xylose and glucose were respectively: 73,45 and $93 \%$ in man and 63,48 and $68 \%$ in rat. Thus, xylose values were similar in man and rat, whereas faecal excretions of arabinose $(P<0.01)$ and glucose $(P<0.05)$ were higher in man. 
Table 1. Composition and faecal recovery of dietary fibre in wheat bran

(Mean values and standard deviations; dietary fibre intake was $16 \cdot 14 \mathrm{~g} / \mathrm{d}$ in man and $0.88 \mathrm{~g} / \mathrm{d}$ (mean value) in rat)

\begin{tabular}{|c|c|c|c|c|c|}
\hline & \multirow{3}{*}{$\begin{array}{c}\text { Dietary fibre } \\
\text { composition } \dagger \\
\text { (g/kg dry matter) }\end{array}$} & \multicolumn{4}{|c|}{ Faecal excretion $(\%)$} \\
\hline & & \multicolumn{2}{|c|}{$\operatorname{Man}(n 6)$} & \multicolumn{2}{|c|}{ Rat $(n 5)$} \\
\hline & & Mean & SD & Mean & SD \\
\hline Rhamnose + fucose & 0 & 0 & 0 & 0 & 0 \\
\hline Arabinose & 133 & $73^{* *}$ & 5 & 63 & 3 \\
\hline Xylose & 183 & 45 & 4 & 48 & 2 \\
\hline Mannose & 3 & 36 & 29 & 99 & 26 \\
\hline Galactose & 11 & 94 & 29 & 21 & 5 \\
\hline Glucose & 169 & $93^{*}$ & $21 \S$ & 68 & 3 \\
\hline Sum of neutral sugars & 499 & 66 & 9 & 59 & 2 \\
\hline Uronic acids & 31 & - & - & $33 \ddagger$ & - \\
\hline Klason lignin & 67 & - & - & 96 & 18 \\
\hline Total & 597 & - & - & 61 & 3 \\
\hline
\end{tabular}

Mean values were significantly different from those of rats: $* P<0.05, * * P<0 \cdot 01$.

$\dagger$ Isolated by using the method of Asp et al. (1983) and further characterized by gas-liquid chromatography (Theander \& Åman, 1979).

Pooled samples from five rats.

$\S$ A modified $t$ test was used due to the unequal variances.

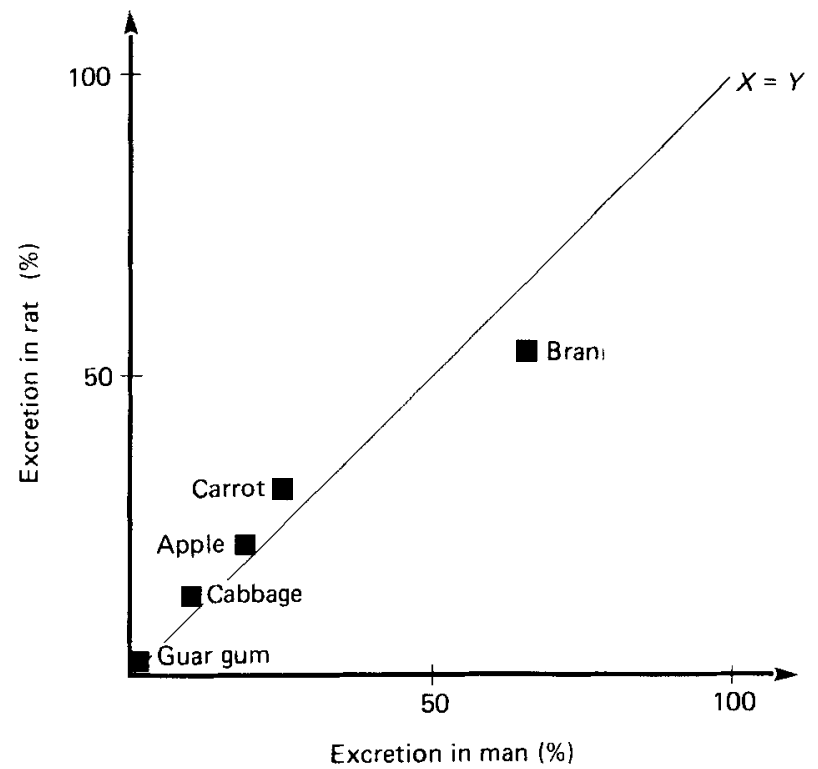

Fig. 1. Faecal excretion ( $\%$ of intake) of main neutral sugar fibre components in man and rat given wheat bran, apple, cabbage, carrot or guar gum. The regression equation between man and rat was $Y=0.86 X+4 \cdot 06, r 0.99$.

Apple. The apple fibre preparation studied contained $766 \mathrm{~g}$ dietary fibre $/ \mathrm{kg}$, with approximately $50 \%$ glucose and $20 \%$ uronic acids. Significant amounts of arabinose, xylose, galactose and lignin were also detected (Table 2).

The fermentability of the fibre in apple was very similar in both man and rat. The faecal recovery of the neutral sugars averaged $19 \%$ in man and $22 \%$ in rat (Table 2 and Fig. 1). Excretion of the main components arabinose, xylose, galactose and glucose was also similar 
Table 2. Composition and faecal recovery of dietary fibre in apple

(Mean values and standard deviations; dietary fibre intake was $18.4 \mathrm{~g} / \mathrm{d}$ in man and $0.74 \mathrm{~g} / \mathrm{d}$ (mean value) in rat)

\begin{tabular}{|c|c|c|c|c|c|}
\hline & \multirow{3}{*}{$\begin{array}{c}\text { Dietary fibre } \\
\text { composition* } \\
\text { (g/kg dry matter) }\end{array}$} & \multicolumn{4}{|c|}{ Faecal excretion $(\%)$} \\
\hline & & \multicolumn{2}{|c|}{$\operatorname{Man}(n 6)$} & \multicolumn{2}{|c|}{ Rat $(n 5)$} \\
\hline & & Mean & SD & Mean & SD \\
\hline Rhamnose + fucose & 10 & 27 & 29 & 50 & 15 \\
\hline Arabinose & 60 & 5 & 5 & 4 & 4 \\
\hline Xylose & 59 & 12 & 11 & 15 & 10 \\
\hline Mannose & 22 & 23 & 29 & 27 & 18 \\
\hline Galactose & 55 & 4 & 12 & 7 & 7 \\
\hline Glucose & 360 & 26 & 38 & 27 & 19 \\
\hline Sum of neutral sugars & 566 & 19 & 26 & 22 & 15 \\
\hline Uronic acids & 159 & - & - & 7 & 7 \\
\hline Klason lignin & 41 & - & - & 114 & 9 \\
\hline Total & 766 & - & - & 24 & 12 \\
\hline
\end{tabular}

* Isolated by using the method of Asp et al. (1983) and further characterized by gas-liquid chromatography (Theander \& Åman, 1979).

Table 3. Composition and faecal recovery of dietary fibre in cabbage

(Mean values and standard deviations; dietary fibre intake was $18.4 \mathrm{~g} / \mathrm{d}$ in man and $0.90 \mathrm{~g} / \mathrm{d}$ (mean value) in rat)

\begin{tabular}{|c|c|c|c|c|c|}
\hline & \multirow{3}{*}{$\begin{array}{c}\text { Dietary fibre } \\
\text { composition* } \\
\text { (g/kg dry matter) }\end{array}$} & \multicolumn{4}{|c|}{ Faecal excretion $(\%)$} \\
\hline & & \multicolumn{2}{|c|}{$\operatorname{Man}(n 6)$} & \multicolumn{2}{|c|}{ Rat ( $n 5)$} \\
\hline & & Mean & SD & Mean & SD \\
\hline Rhamnose + fucose & 16 & 31 & 11 & 20 & 7 \\
\hline Arabinose & 101 & 2 & 3 & 3 & 1 \\
\hline Xylose & 27 & 6 & 6 & 21 & 6 \\
\hline Mannose & 15 & 8 & 4 & 14 & 8 \\
\hline Galactose & 58 & 8 & 8 & 2 & 3 \\
\hline Glucose & 220 & 13 & 10 & 19 & 10 \\
\hline Sum of neutral sugars & 437 & 10 & 7 & 13 & 6 \\
\hline Uronic acids & 252 & - & - & 12 & 9 \\
\hline Klason lignin & 14 & - & - & 124 & 53 \\
\hline Total & 703 & - & - & 15 & 8 \\
\hline
\end{tabular}

* Isolated by using the method of Asp et al. (1983) and further characterized by gas-liquid chromatography (Theander \& Áman, 1979).

in the two species. Although there was considerable individual variation in both man and rat given this material, the mean values were in good agreement.

Cabbage. The dietary fibre content in the cabbage preparation was $703 \mathrm{~g} / \mathrm{kg}$. Approximately $70 \%$ of the fibre consisted of glucose and uronic acids. Other fibre components detected in significant amounts were arabinose and galactose (Table 3 ).

Cabbage was an easily fermented dietary fibre and only 10 and $13 \%$ of the neutral-fibre saccharides were recovered in faeces from man and rat respectively (Table 3 and Fig. 1). Both species showed similar ability to degrade the main components, arabinose, galactose and glucose. 
Table 4. Composition and faecal recovery of dietary fibre in carrot

(Mean values and standard deviations; dietary fibre intake was $19.4 \mathrm{~g} / \mathrm{d}$ in man and $0.87 \mathrm{~g} / \mathrm{d}$ (mean value) in rat)

\begin{tabular}{|c|c|c|c|c|c|}
\hline & \multirow{3}{*}{$\begin{array}{c}\text { Dietary fibre } \\
\text { composition* } \\
\text { (g/kg dry matter) }\end{array}$} & \multicolumn{4}{|c|}{ Faecal excretion $(\%)$} \\
\hline & & \multicolumn{2}{|c|}{$\operatorname{Man}(n 6)$} & \multicolumn{2}{|c|}{ Rat $(n 5)$} \\
\hline & & Mean & SD & Mean & SD \\
\hline Rhamnose + fucose & 23 & 31 & 36 & 28 & 7 \\
\hline Arabinose & 68 & 3 & 2 & 5 & 4 \\
\hline Xylose & 10 & 33 & 32 & 44 & 17 \\
\hline Mannose & 14 & 9 & 8 & 55 & 17 \\
\hline Galactose & 101 & 3 & 5 & 4 & 7 \\
\hline Glucose & 246 & 42 & 31 & 47 & 18 \\
\hline Sum of neutral sugars & 462 & 25 & 18 & 29 & 9 \\
\hline Uronic acids & 323 & - & - & 11 & 7 \\
\hline Klason lignin & 14 & - & - & 86 & 26 \\
\hline Total & 799 & - & - & 24 & 9 \\
\hline
\end{tabular}

* Isolated by using the method of Asp et al. (1983) and further characterized by gas-liquid chromatography (Theander \& Åman, 1979).

Carrot. The total dietary fibre content in the carrot preparation was $799 \mathrm{~g} / \mathrm{kg}$. The relative distribution of main components was rather similar to that in cabbage (Table 4).

Similar amounts of the neutral fibre-saccharides were recovered in faeces in both species. The faecal recovery was $25 \%$ in man $v .29 \%$ in rats (Table 4 and Fig. 1). The main neutral-dietary-fibre components arabinose, galactose and glucose also showed a similar availability to bacterial breakdown. However, there was large individual variation, especially in the human experiment.

Guar gum. Guar gum, which is a rather pure galactomannan, was almost completely fermented in rat, whereas in man it seemed somewhat more resistant (Table 5). Of the neutral sugars $13 \%$ were excreted in man $v .4 \%$ in rat. However, during the guar-gum feeding period in man, additional xylose, glucose and rhamnose + fucose appeared in the faeces. The additional fucose and possibly some of the glucose excreted could be explained by increased mucus secretion. However, most of the glucose excretion was derived from a glucan that had many of the characteristics of starch in vitro. The large standard deviation of glucose is because one subject excreted very large quantities of this material. In the rat experiment glucan excretion, corrected for free glucose, was $75 \%$ of the ingested amount. The glucan, however, was a minor component $(<10 \mathrm{~g} / \mathrm{kg})$ in the guar-gum preparation, and the rat experiment did not provide evidence for faecal starch excretion during feeding with guar gum. Excluding the faecal excretion of these non-fibre saccharides and only considering the excretion of the main fibre components mannose and galactose improved the correlation between man and rat. Less than $2 \%$ of the mannose and the galactose were recovered in the faeces of both species (Fig. 1 and Table 6).

\section{Fermentation of uronic acids and lignin}

In the present study, the faecal excretions of uronic acids and lignin were analysed in rats but not in man. However, the results obtained in rats were very much the same as those reported earlier from human investigations.

No bacterial degradation of lignin was seen in rats, which is in good agreement with studies in man (Dintzis et al. 1979; Van Dokkum et al. 1983). The uronic acids in apple, 
Table 5. Composition and faecal recovery of dietary fibre in guar gum

(Mean values and standard deviations; dietary fibre intake was $18.2 \mathrm{~g} / \mathrm{d}$ in man and $0.88 \mathrm{~g} / \mathrm{d}$ (mean value) in rat)

\begin{tabular}{|c|c|c|c|c|c|}
\hline & \multirow{3}{*}{$\begin{array}{c}\text { Dietary fibre } \\
\text { composition* } \\
\text { (g/kg dry matter) }\end{array}$} & \multicolumn{4}{|c|}{ Faecal excretion $(\%)$} \\
\hline & & \multicolumn{2}{|c|}{$\operatorname{Man}(n 3)$} & \multicolumn{2}{|c|}{ Rat ( $n 5)$} \\
\hline & & Mean & SD & Mean & SD \\
\hline Rhamnose + fucose & 0 & $\dagger$ & - & 0 & 0 \\
\hline Arabinose & 16 & 5 & 9 & 6 & 5 \\
\hline Xylose & 0 & $\dagger$ & - & 0 & 0 \\
\hline Mannose & 546 & 0 & 0 & 1 & 0 \\
\hline Galactose & 325 & 1 & 2 & 4 & 2 \\
\hline Glucose & 8 & $330 \dagger$ & 440 & 75 & 59 \\
\hline Sum of neutral sugars & 895 & 13 & 14 & 4 & 1 \\
\hline Uronic acids & 18 & - & - & $41+$ & - \\
\hline Klason lignin & 0 & - & - & 0 & 0 \\
\hline Total & 913 & - & - & 4 & 1 \\
\hline
\end{tabular}

* Isolated by using the method of Asp et al. (1983) and further characterized by gas-liquid chromatography (Theander \& Aman, 1979).

$\dagger$ See p. 492.

$\ddagger$ Pooled samples from five rats.

Table 6. Faecal excretion of main neutral fibre components $(\%$ of intake) and faecal dry weight increment ( $\mathrm{g} / \mathrm{g}$ added fibre)

(Mean values with their standard errors)

\begin{tabular}{|c|c|c|c|c|c|c|c|c|}
\hline \multirow[b]{3}{*}{ Fibre } & \multicolumn{4}{|c|}{$\begin{array}{c}\text { Faecal excretion of main neutral } \\
\text { fibre components }(\%)\end{array}$} & \multicolumn{4}{|c|}{$\begin{array}{c}\text { Faecal dry weight increment } \\
\text { (g/g added fibre) }\end{array}$} \\
\hline & \multicolumn{2}{|c|}{ Man } & \multicolumn{2}{|c|}{ Rat } & \multicolumn{2}{|c|}{ Man } & \multicolumn{2}{|c|}{ Rat } \\
\hline & Mean & SEM & Mean & SEM & Mean & SEM & Mean & SEM \\
\hline Wheat bran & 66 & 3 & 59 & 1 & $1 \cdot 18$ & 0.09 & 0.91 & 0.03 \\
\hline Apple & 19 & 11 & 21 & 7 & $0 \cdot 35$ & 0.08 & 0.45 & 0.11 \\
\hline Cabbage & 9 & 3 & 12 & 3 & 0.46 & 0.04 & 0.50 & 0.08 \\
\hline Carrot & 26 & 8 & 30 & 5 & 0.50 & 0.06 & 0.62 & 0.07 \\
\hline Guar gum & 1 & 1 & 2 & 0 & 0.29 & $0 \cdot 14$ & 0.39 & 0.04 \\
\hline
\end{tabular}

cabbage and carrot were almost completely fermented in rats; only $7-12 \%$ of the intakecould be detected in faeces. These results are similar to those obtained in man. Pure pectin, mostly consisting of uronic acids, has been shown to be completely fermented (Cummings et al. 1979). Thus, the fermentability of uronic acids and lignin can be assumed to be similar in man and rat.

\section{Faecal bulking capacity}

A good correlation ( $r 0.97$, regression coefficient 0.56 ) between faecal dry weight increment in man and rat was seen (Fig. 2 and Table 6). Wheat bran, as many studies have shown, produces the largest effect on stool weight; that of apple, cabbage, carrot and guar gum being much less pronounced. The faecal dry weight increment in rats fed on guar gum was due to increased excretion of fat and protein (Nyman \& Asp, 1982). 


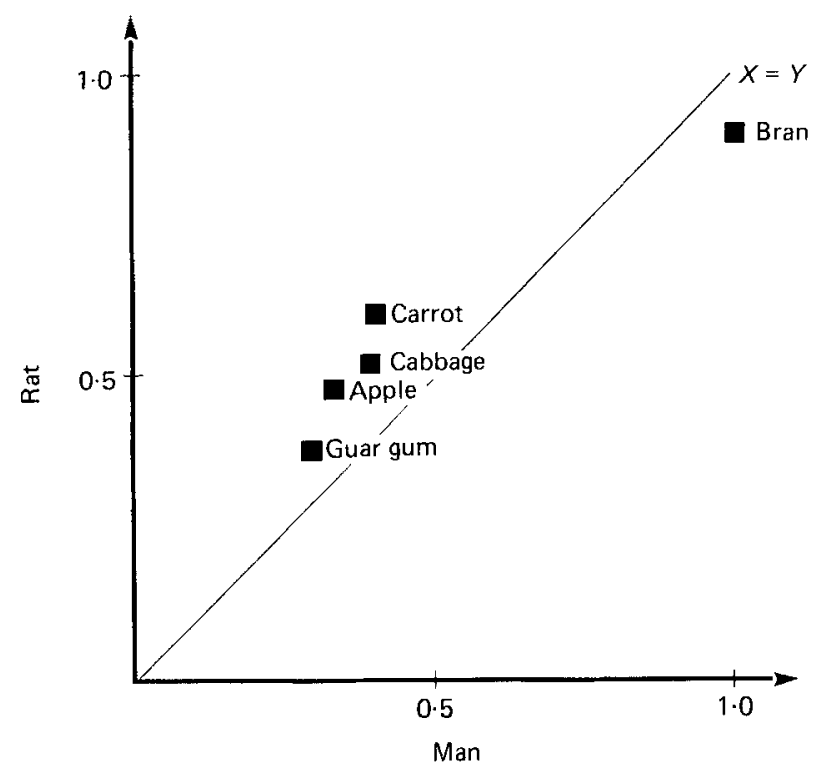

Fig. 2. Faecal dry weight increment ( $\mathrm{g} / \mathrm{g}$ added fibre) in man and rat given wheat bran, apple, cabbage, carrot or guar gum. The regression equation between man and rat was $Y=0.56 X+0.26, r 0.97$.

The amount of soluble fibre, measured with the gravimetric method of Asp et al. (1983), was quite different in the various fibre preparations. Of the fibre in apple, cabbage and carrot $23-29 \%$ were soluble $v .8 \%$ of the wheat-bran fibre. In contrast, guar gum was almost completely soluble. Figs 1 and 2 show that the more soluble the fibre the greater the extent of its degradation in the gut and the smaller the increment in stool weight it produces.

\section{General discussion and conclusions}

The present study shows that breakdown of dietary fibre in the intestinal tract was similar in both man and rat. On the whole soluble dietary fibre was more readily broken down than insoluble fibre (Fig. 1 and Table 6). Whatever method is used to measure dietary fibre and its components it is clear that the major part of it is degraded in the gut, with the exception of wheat-bran fibre.

The individual variation in the breakdown of dietary fibre, i.e. the standard deviation, was much smaller for wheat bran (Table 1) than for apple and carrot (Tables 2 and 4) in both man and rat. It could be questioned whether a longer adaptation period to the diet would have reduced the standard deviation. Earlier studies on rats have shown that the individual variation in fibre breakdown tended to go down with period after feeding with an easily fermented type of fibre (Nyman \& Asp, 1985b). The composition of the colon microffora, however, has been reported to be relatively constant in man, and cannot be fundamentally changed by nutrition (Savage, 1983). The differences between individuals are more pronounced than the alterations achieved after changes in the diet (Cummings, 1983 b).

In most materials, including those studied in the present investigation, the total glucan value is a good measure of the cellulose content (Theander \& $\AA$ man, 1981). In the rat experiments $32-81 \%$ of this glucan was fermented and there was no indication of an increased glucan excretion due to any of the fibre preparations tested. In the human study cellulose was measured specifically and it was clear that some of the excreted glucan was not cellulose but a substance that behaved similarly to partly degraded starch. In the study of guar gum, which contains no significant glucose, large amounts of this non-cellulosic 
glucose were excreted particularly by one subject, who also had a fast transit time. Starch resistant to amylase is known to occur in human foods (Englyst et al. 1982; Johansson et al. 1984; Siljeström et al. 1985). It may be broken down incompletely in the large intestine either because there is insufficient time for microbial action or, in the presence of alternative carbohydrates substrates which are more soluble, such as guar gum, resistant starch is saved.

Van Soest et al. (1983) have observed in a series of comparative studies of fermentation of dietary fibre in man and other animals that fermentation is largely dependent on body size. Larger animals such as man and pigs digest fibre to a greater extent than smaller animals, such as the rat. They have therefore suggested that rodents are of no use when studying problems in human nutrition. Small animals need more energy per unit body-weight, which means faster transit and lower fibre utilization.

In the present study there was no indication of a more-extensive degradation of fibre in man than in rats. In contrast wheat bran was somewhat more resistant to bacterial degradation in man. On the whole, however, the agreement was good, most fibre being totally degraded. Thus it seems that this rat model can be used to predict bacterial degradation and the bulking effect of various types of dietary fibre in man. It may also be used to study the effects of various processes, e.g. extrusion cooking and baking, on dietary fibre.

\section{REFERENCES}

Asp, N.-G., Johansson, C.-G., Hallmer, H. \& Siljeström, M. (1983). Journal of Agricultural and Food Chemistry 31, $476-482$.

Björck, I., Nyman, M. \& Asp, N.-G. (1984). Cereal Chemistry 61, 174-179.

Björck, I., Nyman, M. Pedersen, B., Siljeström, M., Asp, N.-G. \& Eggum, B. O. (1986). Journal of Cereal Science 4, $1-11$.

Cummings, J. H. (1981). British Medical Bulletin 37, 65-70.

Cummings, J. H. (1982). In Dietary Fiber in Health and Disease, pp. 9-22 [G. Vahouny and D. Kritchevsky, editors]. New York: Plenum Press.

Cummings, J. H. (1983a). Lancet i, 1206-1209.

Cummings, J. H. (1983 b). In Nutrition and the Intestinal Flora, pp. 77-86 [B. Hallgren, editor]. Uppsala, Sweden: Almqvist \& Wiksell.

Cummings, J. H. \& Branch, W. J. (1982). In Dietary Fiber in Health and Disease, pp. 313-325 [G. Vahouny and D. Kritchevsky, editors]. New York: Plenum Press.

Cummings, J. H., Southgate, D. A. T., Branch, W. J., Houston, H., Jenkins, D. J. A. \& James, W. P. T. (1978). Lancet i, 5-8.

Cummings, J. H., Southgate, D. A. T., Branch, W. J., Wiggins, H. S., Houston, H., Jenkins, D. J. A., Jivraj, T. \& Hill, M. J. (1979). British Journal of Nutrition 41, 477-485.

Dekker, R. F. H. \& Richards, G. N. (1973). Journal of the Science of Food and Agriculture 24, 375-379.

Dintzis, F. R., Legg, L. M., Deatherage, W. L., Baker, F. L., Inglett, G. E., Jacob, R. A., Reck, S. J., Munoz, J. M., Klevay, L. M., Sandstead, H. H. \& Shuey, W. C. (1979). Cereal Chemistry 56, 123-127.

Englyst, H., Wiggins, H. S. \& Cummings, J. H. (1982). Analyst 107, 307-318.

Heller, S. N., Hackler, L. R., Rivers, J. M., Van Soest, P. J., Roe, D. A., Lewis, B. A. \& Robertson, J. (1980). American Journal of Clinical Nutrition 33, 1734-1744.

Johansson, C.-G., Siljeström, M. \& Asp, N.-G. (1984). Zeitschrift für Lebensmittel Untersuchung und Forschung 179, 24-28.

Keys, J. E., Van Soest, P. J. \& Young, E. P. (1970). Journal of Animal Science 31, 1172-1177.

McNeil, N. I., Cummings, J. H. \& James, W. P. T. (1978). Gut 19, 819-822.

Mason, V. C. \& Palmer, R. (1973). Acta Agriculturae Scandinavica 23, 141-1 50.

Nyman, M. \& Asp, N.-G. (1982). British Journal of Nutrition 47, 357-366.

Nyman, M. \& Asp, N.-G. (1985a). Scandinavian Journal of Gastroenterology 20, 887-895.

Nyman, M. \& Asp, N.-G. (1985b). British Journal of Nutrition 54, 635-643.

Nyman, M., Asp, N.-G., Pedersen, B. \& Eggum, B. O. (1985). Journal of Cereal Science 3, 207-219.

Paul, A. A. \& Southgate, D. A. (1978). McCance and Widdowson's The Composition of Foods. London: H.M. Stationery Office.

Rotenberg, S., Eggum, B. O., Hegedüs, M. \& Jacobsen, I. (1982). Acta Agriculturae Scandinavica 32, 309-319.

Savage, D. C. (1983). In Proceedings of Fibre in Human and Animal Nutrition Symposium, pp. 125-129 [G. Wallace and L. Bell, editors]. Wellington, New Zealand: The Royal Society of New Zealand. 
Sawardeker, J. S., Sloneker, J. H. \& Jeanes, A. (1965). Analytical Chemistry 37, 1602-1604.

Siljeström, M. \& Asp, N.-G. (1985). Zeitschrift für Lebensmittel Untersuchung und Forschung 181, 4-8.

Theander, O. \& Åman, P. (1979). Swedish Journal of Agricultural Research 9, 97-106.

Theander, O. \& Åman, P. (1981). In The Analysis of Dietary Fiber in Food, pp. 51-70 [W. P. T. James and O.

Theander, editors]. New York and Basel: Marcel Dekker Inc.

Vahouny, G. \& Kritschevsky, D. [editors] (1982). Dietary Fiber in Health and Disease. New York: Plenum Press.

Van Dokkum, W., Pikaar, N. A. \& Thissen, J. T. N. M. (1983). British Journal of Nutrition 50, 61-74.

Van Soest, P. J., Jeraci, J., Foose, T., Wrick, K. \& Ehle, F. (1983). In Proceedings of Fibre in Human and Animal Nutrition Symposium, pp. 75-80 [G. Wallace and L. Bell, editors]. Wellington, New Zealand: The Royal Society of New Zealand.

Wyman, J. B., Heaton, K. W., Manning, A. P. \& Wicks, A. C. B. (1976). American Journal of Clinical Nutrition 29, 1474-1479. 